\title{
Development and Teaching Application of New Intelligent Courseware in "Sports Economics"
}

\author{
http://dx.doi.org/10.3991/ijet.v11i05.5694 \\ Youguo Shi, Shuqin Chen \\ Bengbu Medical College, Bengbu, Anhui, China
}

\begin{abstract}
During the development of information technology, the application of multimedia courseware in teaching activities has become a trend of current education. Flash is widely applied in multimedia courseware making by virtue of its advanced technology, good interactivity and easy propagation etc. Based on the above background, this paper designs a new intelligent courseware based on Flash technology through summarizing the researches of domestic and overseas scholars about the application of Flash technology in teaching. Meanwhile, this paper analyzes design thought and major structure of courseware system. On this basis, contrastive teaching experiment and quantitative statistics are applied to demonstrate application effect of this intelligent courseware system in Sports Economics course teaching. The results verify that the new intelligent courseware can greatly improve students' learning interest, learning initiative and academic performance, and plays a significant helping role in college sports specialty teaching. Besides, it also has strong reference value in teaching other courses.
\end{abstract}

Index Terms-multimedia, design and application, Sports Economics, intelligent Flash courseware

\section{INTRODUCTION}

Flash is vector-based animation making software which is especially designed by Macromedia for internet. Meanwhile, it is one of the most fashionable animation making software. It is a multimedia courseware system which is based on Flash animation technology and integrates teaching contents, methods, key and difficult points [1]. Flash not just helps teachers make wonderful multimedia courseware, but also can be integrated with other $\mathrm{mx}$ series of products to make bright and colorful flash works. For the same content, the capacity of making it by flash is smaller than that of making it by other software [2]. The reason why we make the courseware with flash is not just that flash courseware capacity is small, but also that it has supper ability in animation making aspect [3]. In recent years, with rapid development of informatization and multimedia technology, the courseware system based on Flash technology has been increasingly developed and widely applied in teaching practice of each specialty. It greatly assists improvement of teaching effect [4]. Based on this, many experts and scholars in education field focus on teaching assistance application of Flash courseware and have gained some experience and results. García and Quirós applied flash technology in geometry course. Macromedia Flash is used in animation development; it is a tool which can create very small vectorial graphics files, so it promotes their electronic transmission to any user linked to the network. They gained satisfying teaching effect [5]. In order to demonstrate how the application of interactive flash games in three animal science courses strengthens students' learning and understanding of complex concepts and difficult new materials and increases examination scores, Flash games were used as the tools in Feeds and Feeding, Applied Animal Nutrition and Animal Reproduction courses taught at the University of Minnesota, Crookston. The results show that Flash games can improve students' examination scores and gain satisfying student support rate [6]. Zeng et al. (2010) studied a Flash courseware system applied in Medical Statistics course teaching. This courseware system takes animation as the carrier and dynamically shows teaching content, thus greatly enhancing teaching effect [7]. Chen (2010) analyzed the application of Flash multimedia animation combined with training in basketball teaching, elaborated the making process of courseware system and analyzed the application mode of the courseware in actual teaching by taking half-time covering and intensive training for example [8]. Xu et al. (2012) deeply analyzed the application superiority of Flash multimedia courseware in sports specialty teaching and indicated that the introduction of Flash multimedia courseware could further stimulate students' learning interest, highlight key teaching points and help students establish clear movement representation [9].

Sports Economics is one of sports science disciplines, and it studies practical economics of sports industry with the analysis method of economics [10]. At present, sports industry gets all-round development worldwide. How to teach Sports Economics well urgently needs out concern. Previous sports teaching mostly pays attention to skills and ignores theories, because for the students majoring in sports, their basic knowledge of mathematics is poor. Sports Economics as an emerging discipline has no uniform teaching material presently, and the teaching materials of economics specialty are mostly followed. Students generally express the theoretical property of teaching materials is too strong, and the knowledge is hard to understand. Thus, their learning interest is not strong [11].

In view of this, this research adopts multimedia Sports Economics courseware set which is produced with flash animation technology in order to offer good reference for Sports Economics teaching. Its innovations are as follows: firstly, the intelligent courseware set can utilize common computer and specific program to display all teaching contents of Sports Economics on multimedia screen in the form of animation; secondly, the specific program involves multiple sub-programs such as image, video, test and sound processing, and one main program which can automatically enter or quit the sub-programs according to the button; thirdly, the contents and sequence of image, video, text and sound are completely in accordance with the sequence of all teaching contents and chapters. 


\section{OVERVIEW OF NEW INTELLIGENT FLASH COURSEWARE SYSTEM DESIGN}

\section{A. Analysis of design thought}

The design of courseware system is based on Flash technology. Besides, program compiling, multimedia structure and informatization module etc. are introduced. Course teaching content of Sports Economics is included, and teaching contents of relevant chapters are displayed on the multimedia screen in the form of animation. The objective of courseware system design is as below: the teacher just needs to choose the teaching chapter of Sports Economics with Flash software or player to carry out courseware identification and open the courseware system needed. In this way, the title and teaching content can be displayed in the multimedia screen in an integrated way. The teacher can explain and demonstrate the teaching content through "touch", "slide", "magnify" and "narrow" operations, which really achieves teaching dynamics, intelligence and entertainment. Main program design flow chart of courseware system is shown in figure 1.

Figure 1 shows program design flow chart of flash courseware system. Based on this design idea, actual visual interface of system includes 4 main buttons: starting procedure, courseware playing, the previous scene and the next scene. The four buttons are the manipulation buttons of teachers. The functions of four buttons are introduced as follows:

(1) Starting procedure button: start courseware system and display tree-shaped selection chart of teaching chapters.

(2) Courseware playing button: the chapter contents in Flash courseware prepared in advance are displayed on the multimedia screen in the form of text, image, video, sound and animation. The teacher may touch the screen to choose corresponding chapter for teaching and presentation.

(3) The previous scene button: according to teaching needs, the teacher may manipulate this button to turn to the previous teaching scene. At this moment, the content of previous teaching scene will be shown on the multimedia screen.

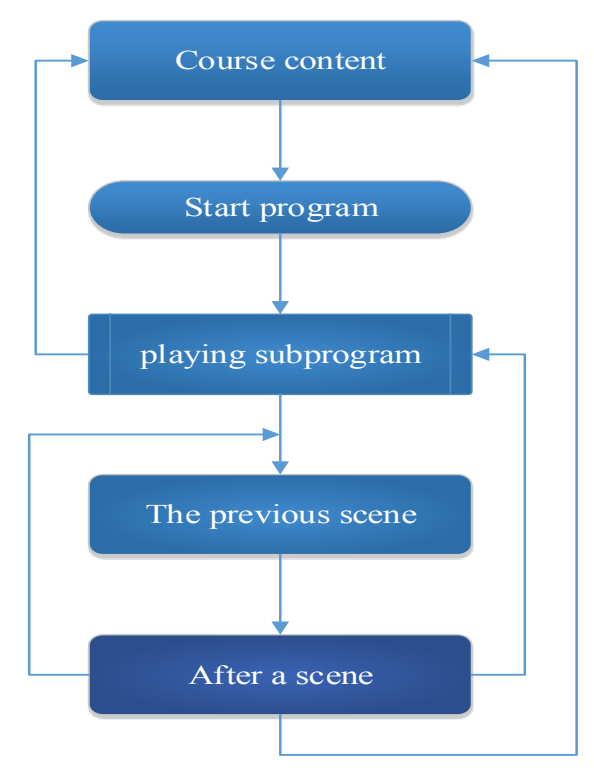

Figure 1. Program design flow chart of courseware system

(4) The next scene button: according to teaching needs, the teacher may manipulate this button to turn to the next teaching scene. At this moment, the content of next teaching scene will be shown on the multimedia screen.

\section{B. Introduction to modular structure}

Based on the above structure design thought, modular structure of courseware system can be designed in detail. To be more specific, according to the demand of Sports Economics, modular structure of Flash courseware system is designed as figure 2 .

As shown in figure 2, the intelligent Flash courseware mainly includes 4 application modules: text module, image module, video module and sound module. During importing the contents of Sports Economics in the courseware, it is necessary to overall apply functions of the above 4 modules and complete courseware system making through importing information, creating elements, creating key frames, scene including and setting state information etc.

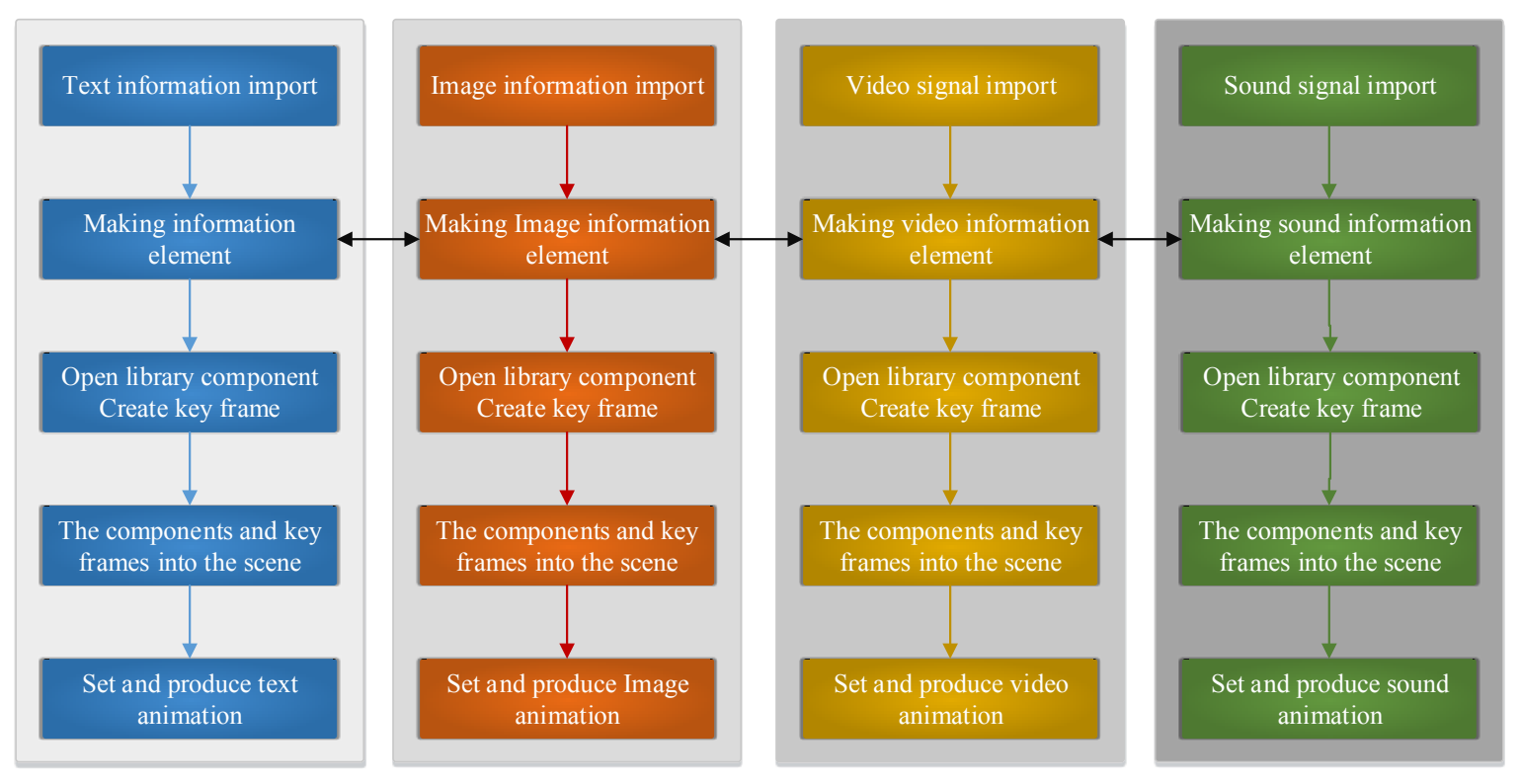

Figure 2. Modular structure chart of Flash courseware system 
PAPER

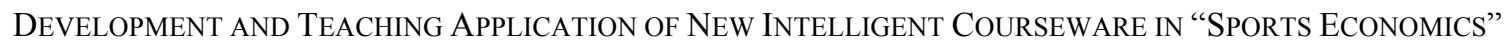

In general, under the framework based on Flash technology, the teacher may make, import, modify and improve information of Sports Economics courseware and gradually achieve enrichment of courseware teaching content. In specific teaching application, the teacher can display the teaching content and interact with students only through touching the screen. Compared with traditional courseware teaching system, intelligence, interactivity, comprehensiveness and entertainment of this courseware system are more prominent, and its teaching application advantage is significant.

\section{ApPlicAtion OF NEW INTELLIGENT FLASH COURSEWARE IN TEACHING EXPERIMENT OF SPORTS ECONOMICS}

\section{A. Objects of teaching}

The students in Class (1), Class (2), Class (3) and Class (4) who majored in sports and were admitted to the university in 2013 were chosen as the objects. The number of students in each class was 50. The comparison of students in the four classes has no significant statistical difference in age, learning ability, learning interest and cognition of Sports Economics $(\mathrm{P}<0.05)$. To highlight the effect of intelligent Flash courseware in the teaching, contrastive teaching method was adopted in the specific teaching practice. Class (1) and Class (2) served as the control group, while Class (3) and Class (4) serves as the experimental group.

\section{B. Teaching design analysis}

Sports Economics includes 64 class hours in total, and this course was mainly taught by theory teaching. In experiment teaching design, "Flash courseware system teaching method" was applied for the students in the experimental class. The course content was imported in the courseware system, and audio-visual teaching practice based on Flash technology was organized. For the students in control class, traditional "classroom theory teaching method" was used. After teaching for 64 class hours, questionnaire survey and quantitative statistics were used to gather learning interest, test scores, teaching cognitions and other indicators of students in both groups so as to complete comprehensive analysis of teaching effect.

\section{Statistical method}

Based on Teaching Effect Investigation and Analysis Table, the students in both groups were overall investigated to collect students' learning interest degree and teaching cognition conditions. 200 questionnaires were distributed, and 195 effective questionnaires were recovered, with the recovery rate of $97.5 \%$. Meanwhile, EXCLE software was applied to sort the data and make the chart files so as to accomplish statistical analysis of teaching effect.

\section{Experiment teaching strategy}

(1) Teaching strategy of control class

Traditional "classroom theory teaching method" was used to teach the students in the control class.

(2) Teaching strategy of experimental class

For the students in experimental class, the teacher took intelligent Flash courseware system as the carrier, organized and designed "full-cycle dynamic teaching mode" for teaching. Organization flow chart of this teaching mode is as figure 3 .

As shown in figure 3, then implementation of "fullcycle dynamic teaching mode" involves three steps:

Firstly, pre-class guidance link. In this ink, the teacher regarded Flash courseware system as the carrier, introduced rough teaching contents of each chapter of Sports Economics and guided students to view basic teaching condition, knowledge points, key and difficult points. Teaching organization was dominated by "independently inquiry" and supplemented by teacher's teaching. Through the image text, animation and sound information in Flash courseware system, students could visually know learning contents of each chapter of Sports Economics, think over the teaching contents and establish preliminary cognition of course contents. (see figure 4 and 5)
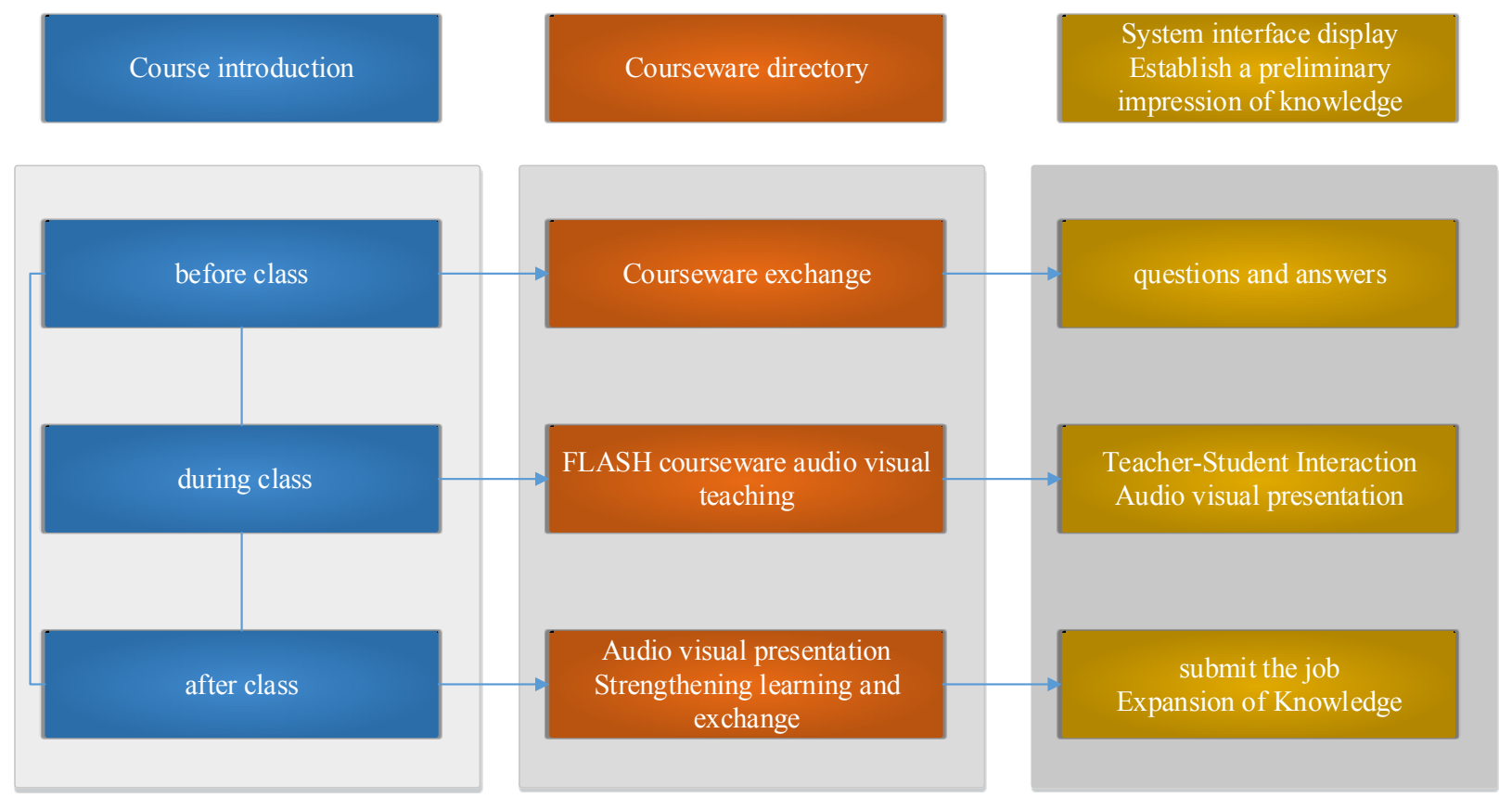

Figure 3. Teaching organization flow chart of intelligent Flash courseware system 


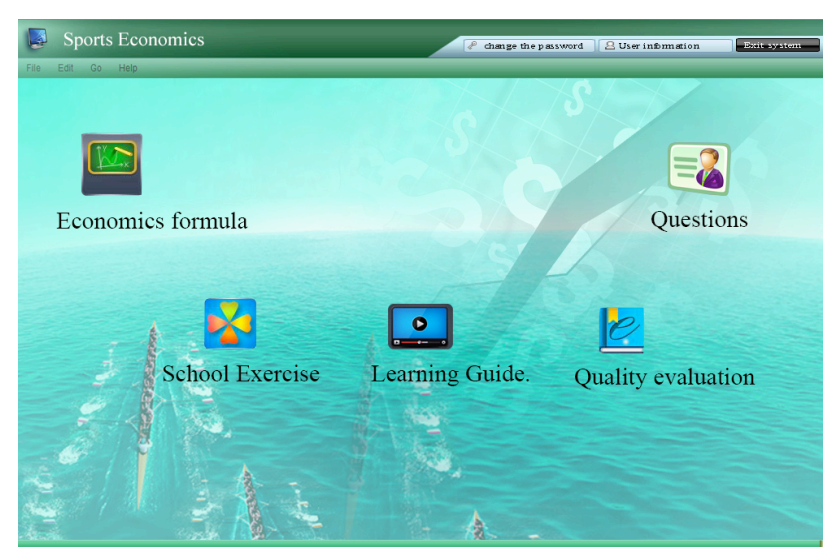

Figure 4. Flash courseware teaching content in pre-class guidance link

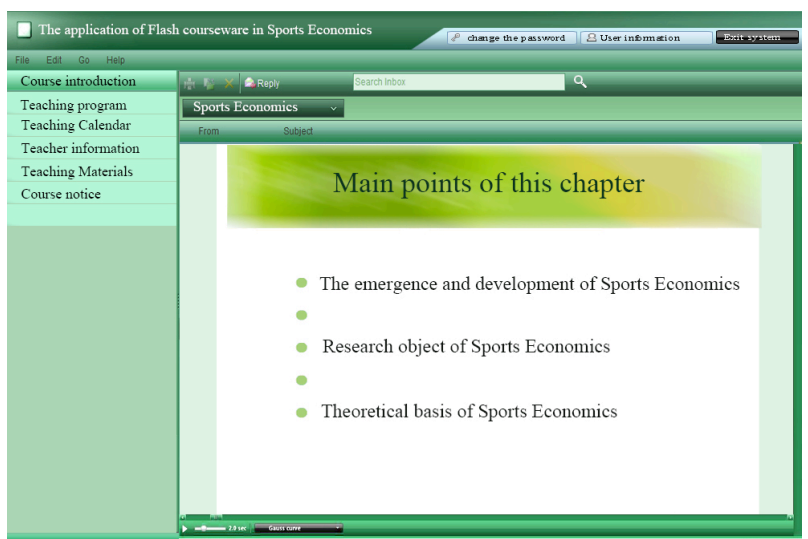

Figure 5. Content of Flash courseware teaching

Secondly, in-class implementation link. In this link, the teacher deemed the resource in Flash courseware system as the carrier to organize teaching. The specific teaching steps are as follows: (1) set courseware attribute, adjust courseware intensity, and display height and sound as well as other parameters according to teaching content; (2) import teaching image, video, animation and sound information, and press F11 button to control courseware playing speed; (3) demonstrate courseware content and play courseware content in the form of button or touch screen; switch courseware teaching content through touching the button off "previous scene" and "next scene"; (4) interactive teaching. During teaching, the teacher may interact and exchange with students, and students may put forward their ideas to improve courseware content. Under teacher's guidance, students may step on the platform and apply set, modify and add functions in Flash courseware system to improve and optimize courseware system contents.
Thirdly, after-class expansion link. This link is the after-class link. The teacher shared courseware contents with students through teaching QQ group and guided students to express their experience about Flash courseware teaching, to write down their experience and to finish after-class assignments.

In the above three teaching link, Flash courseware system becomes the "integrated audio-visual" medium of Sports Economics course teaching, especially in classroom teaching, by immediate modification function of Flash courseware system, students can step on the platform and participate in courseware making and improvement in person. This overturns classroom interaction form of Sports Economics under traditional teaching mode and makes the whole teaching interaction link be more humanized and practical and own more sense of participation

\section{E. Results}

After teaching for 64 class hours, questionnaire survey and final examination were applied to compare learning interest and degree of teaching method recognition of students in experimental class and control class, as shown in Table I and Table II.

It can be seen from Table I that, "Flash courseware system teaching method" can significantly improve the learning interest of students in experimental class $(\mathrm{P}<0.01)$. The students interested in learning account for the overwhelming majority $(94.7 \%)$, while the number of students interested in learning is less than a half in the control group $(44.6 \%)$.

Table II also indicates that students in the experimental group highly recognize "Flash courseware system teaching method", and the recognition degree is as high as $84.5 \%$. The recognition degree of control group for traditional teaching method is only $60.2 \%$. Significant difference exists in teaching method recognition proportion of students in two groups $(\mathrm{P}<0.001)$.

As shown in the figure 6 , excellent ratios of final examination scores of students in experimental class and control class are $40 \%$ and $5 \%$, respectively, while the ratios of students failing in the final examination in experimental class and control class are 0 and 155, respectively. Chisquare test shows the pass rate of students in both groups has significant difference $(\mathrm{P}<0.001)$.

This indicates that intelligent Flash courseware teaching mode is generally accepted by students and has significant improvement effect for students' learning interest and scores.

TABLE I.

STATISTICAL TABLE OF LEARNING INTEREST [NUMBER OF STUDENTS (\%)]

\begin{tabular}{lcccc}
\hline & Very interested & Interested & Not interested & P \\
\hline Experimental class & $70(74.47)$ & $19(20.21)$ & $5(5.32)$ & Chi-square $=61.551$ \\
Control class & $23(25)$ & $18(19.57)$ & $51(55.43)$ & $P<0.001$ \\
\hline
\end{tabular}

TABLE II.

STUDENTS RECOGNITION OF TEACHING METHOD [NUMBER OF STUDENTS (\%)]

\begin{tabular}{|c|c|c|c|c|}
\hline & Very recognize & Generally recognize & Not recognize & Chi-square test \\
\hline Experimental class & $53(54.64)$ & $29(29.9)$ & $15(15.46)$ & \multirow{2}{*}{$\begin{array}{c}\text { Chi-square }=34.9799 \\
\mathrm{P}<0.001\end{array}$} \\
\hline Control class & $15(15.31)$ & $44(44.9)$ & $39(39.8)$ & \\
\hline
\end{tabular}




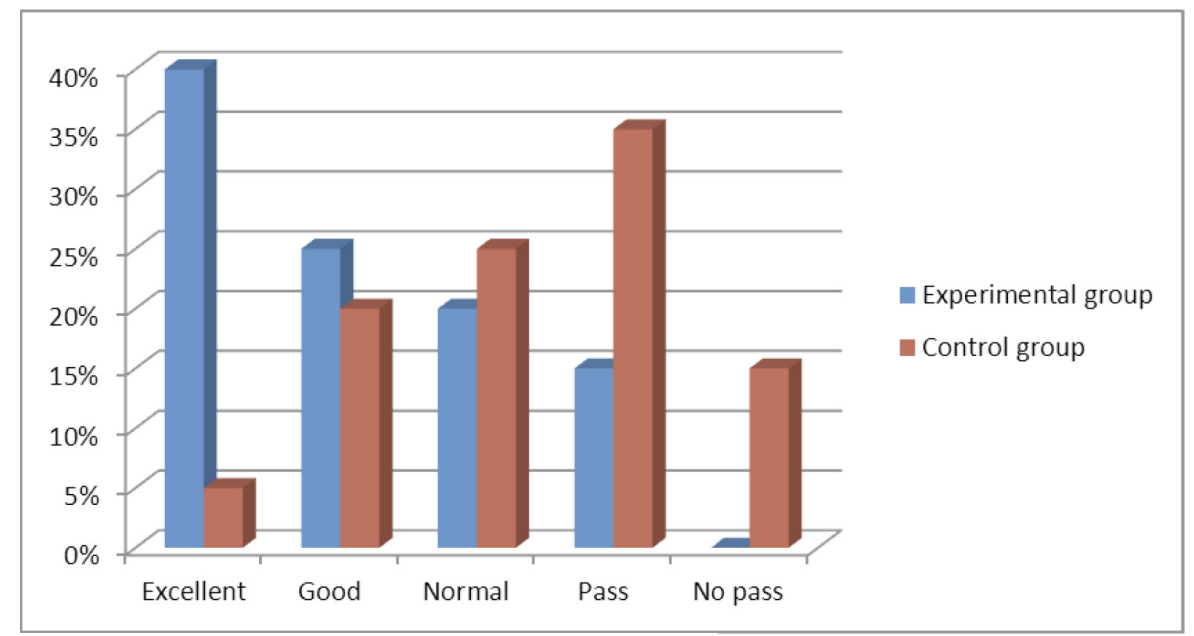

Figure 6. Statistical of final examination scores of students in experimental class and control class

\section{CONCLUSIONS}

Contrastive teaching data show that seeing from learning interest, learning cognition, and final examination scores, the students in experimental class for which intelligent Flash courseware was applied are significantly superior to the students in control class for which traditional courseware teaching was adopted. Through interview with the students in experimental class, most students expressed that, "Sports Economics" classroom based on Flash courseware system is more interesting. Through the "modify, improve, add and share" functions of courseware system, they can step on the platform, discuss courseware making principles with the teacher, and actually operate the courseware making and modification. In this way, they can experience the joys of courseware making and feel the sense of achievement. Besides, intelligent Flash courseware embodies good interactivity and shows richer language element in teaching. The boring formulas of economics can be displayed to students in a more interesting manner. In this way, the students with poor theoretical basis can better understand and remember new knowledge. Meanwhile, the improved courseware set is convenient to use. The image, video, text and sound contents as well as the sequence have been made well according to the teaching content of teaching materials. In addition, the key and difficult points are also included in the courseware. The teacher can apply network resource to further combine FLASH courseware set and improve Flash courseware. In this way, students can further improve their knowledge comprehension level and memory level in visual course teaching.

To sum up, as informatization level of network technology keeps improving, Flash animation software technology shows significant effect in multimedia classroom teaching. The intelligent Flash courseware teaching system is characterized by informatization, intelligence and interaction, so the students in the experimental class gets learning joys which cannot be experienced in traditional courseware teaching mode. Besides, their learning interest and examination scores increase greatly. How to better combine Flash animation technology with traditional multimedia classroom may gradually become an important content in innovation of educational informatization.

\section{REFERENCES}

[1] Ji H.W., "Design and Implementation of a Class of Multiple Choice in Flash Courseware," Computer Development \& Applications, vol. 24, no. 7, pp. 77-83, July 2011.

[2] Ma L., "The Research of College Multimedia Teaching with Applying Flash Technology in the Digital Media Age," Computer Knowledge and Technology, vol. 8, no. 13, pp. 3187-3188, May 2012.

[3] Ding S.J., Xie F., Lu C.Y., "Application of Flash Programming Language in Teaching Courseware," Computer Programming Skills \& Maintenance, vol. 9, no. 6, pp. 116-118, March 2014.

[4] Lai Z.R., "Fabrication of Powerpoint and Flash Courseware for Clinical Biochemistry," Applied Journal of General Practice, vol. 5, no. 3, pp. 263-264, March 2007.

[5] García R.R., Quirós J.S., Santos R.G., González S.M., Fernanz S.M., "Interactive multimedia animation with macromedia flash in descriptive geometry teaching," Computers \& Education, vol. 49, no. 3 , pp. 615-639, June 2007. http://dx.doi.org/10.1016/j.comp edu.2005.11.005

[6] Maiga H.A, Bauer M.L., "Using Interactive Flash Games to Enhance Students' Learning in Animal Sciences," NACTA Journal, vol. 57, no. 3, pp. 60-66, September 2013.

[7] Zeng F.F., Fang J.Q., "The Development of Animation Courseware for Medical Statistics Based on Flash," Chinese Journal of Medical Education Research, vol. 9, no. 3, pp. 421-423, March 2010.

[8] Chen R.B., Liu B.M., "Discussion and Practice of Flash Animation Design Teaching Reform," Science \& Technology Information, vol. 18, no. 17, pp. 204, September 2010.

[9] Xu W., Wang M., "Application of Multimedia Courseware in PE Teaching," Journal of Harbin Institute of Physical Education, vol. 19, no. 24, pp. 75 , December 2014.

[10] Madden P., "Welfare Economics of 'Financial Fair Play' in a Sports League With Benefactor Owners," Journal of Sports Economics, 2012: 1527002512465759.

[11] Zhang Z., Shi G.S., "On Discussion-based Teaching of Sports Economics - Case Study of Nanjing Institute of Physical Education and Sports," Examination Weekly, vol. 24, no. 14, pp. 97-98, July 2015 .

\section{AUTHORS}

Youguo SHI is a Lecturer of Department of Physical Education and Art, BengBu Medical College, Bengbu 233030, Anhui, China. His research interests include Sports Economics and Multimedia courseware. (shiyouguo1234@yeah.net)

Shuqin CHEN (Corresponding author) is an Assistant teacher of BengBu Medical College, Bengbu 233030, Anhui, China. Her research interests include Art design. (scholar1234@yeah.net)

Submitted 29 March 2016. Published as resubmitted by the authors 04 May 2016. 